REKOGNISI: Jurnal Pendidikan dan Kependidikan

ISSN 2527-5259 Vol.1 No.1 Desember 2016

\title{
MOTIVASI BELAJAR SISWA DENGAN MODEL PEMBELAJARAN MIND MAPPING
}

\author{
Nina Hastina \\ PGSD Universitas Nahdlatul Ulama Sumatera Utara \\ Email :nina_hastina@yahoo.co.id
}

\begin{abstract}
ABSTRAK
Tujuan penelitian ini adalah untuk meningkatkan motivasi belajar PKn siswa dengan menggunakan model pembelajaran mind mapping di kelas IV SD Negeri 104196 Hamparan Perak. Penelitian ini adalah tindakan sebagai meningkatkan motivasi belajar siswa dalam pelajaran PKn dengan menggunakan model pembelajaran mind mapping. Teknik pengumpulan data dengan menggunakan lembar observasi untuk mengukur tingkat motivasi belajar siswa. Adapun teknik analisis data dengan memakai analisis data persentase. Hasil penelitian menunjukkan bahwa pada kondisi awal, sebelum diadakannya tindakan adalah sebanyak 13 orang (52\%) tergolong kategori rendah motivasi belajarnya, 14 orang (48\%) tergolong kategori sedang motivasi belajarnya dan yang tergolong tinggi motivasi belajarnya tidak tampak, pada siklus I setelah dilakukan tindakan, 27 orang (100\%) tergolong sedang motivasi belajarnya dan yang tergolong rendah dan tinggi motivasi belajarnya tidak tampak. Sedangkan pada siklus ke II, tidak ada siswa yang motivasi belajarnya tergolong rendah, 6 orang (22\%) tergolong sedang motivasi belajarnya dan 28 orang (78\%) tergolong tinggi motivasi belajarnya. Model pembelajran mind mapping dapat digunakan sebagai alternatif dalam pembelajaran $P K n$.
\end{abstract}

Kata Kunci : motivasi, PKn, mind mapping 


\begin{abstract}
The problem in this research is "low motivation of students of class IV SDN 104196 in Civics". The purpose of this research is to improve students' motivation to learn civics using mind mapping learning model in the fourth grade primary school 104196 Silver Overlay. This study is an action as increase students' motivation in Civics using mind mapping learning model. The data collection technique using observation sheet to measure the level of student motivation. Data analysis technique using data analysis percentage. Research shows that in the initial conditions, prior to the action are as many as 13 people (52\%) belong to the category of low learning motivation, 14 people (48\%) belong to the category of medium learning motivation and relatively high learning motivation does not seem, at first cycle after the action, 27 (100\%) were classified as learning motivation and were classified as low and high learning motivation does not appear. While on the second cycle, no student is learning motivation is low, 6 (22\%) were classified as learning motivation and 28 people (78\%) is high learning motivation. Model learning mind mapping can be used as an alternative in learning civics.
\end{abstract}

Keywords: motivation, civics, mind mapping

\title{
PENDAHULUAN
}

PKn berupaya membekali siswa dengan berbagai kemampuan tentang cara bersosialisasi dan berinteraksi dengan baik di lingkungan keluarga, sekolah dan masyarakat. Atas dasar pemikiran tersebut maka pendekatan pembelajaran pada mata pelajaran dikembangkan dan penekanan pada kegiatan belajar siswa aktif. Pembelajaran dengan model pembelajaran yang menarik akan memberikan pengaruh terhadap kegiatan belajar siswa, seperti tumbuhnya motivasi belajar. Motivasi disini diartikan sebagai daya penggerak yang mendorong siswa untuk belajar secara mandiri untuk mempelajari berbagai aspek yang terkait dengan masalah-masalah belajar.

Motivasi yang dimaksud adalah penyediaan kondisi dari motif tertentu sehingga peserta didik berkeinginan berbuat sesuatu dan melakukan kegiatan atas kesadaran dari diri tanpa ada keterpaksaan juga motif dapat dipengaruhi oleh faktor-faktor dari luar sehingga pada akhirnya akan tercapai tujuan yang diharapkan

Sardiman (2009: 75) mengatakan "motivasi juga dapat dikatakan serangkaian usaha untuk menyediakan kondisi- kondisi tertentu, sehingga seseorang mau dan ingin melakukan sesuatu, dan bila ia tidak suka, maka akan berusaha untuk meniadakan atau mengelakkan perasaan tidak suka itu. Jadi motivasi itu dapat dirangsang oleh faktor dari luar tetapi motivasi itu adalah tumbuh di dalam diri seseorang".

Hamalik (2008: 105) mengemukakan ada dua pendekatan yang digunakan untuk meninjau dan memahami motivasi, ialah (1) motivasi dipandang sebagai 
suatu proses. Pengetahuan tentang proses ini dapat membantu guru menjelaskan tingkah laku yang diamati dan meramalkan tingkah laku orang lain; (2) menentukan karakteristik proses ini berdasarkan petunjuk-petunjuk tingkah laku seseorang.

Soemanto (2006: 212) berpendapat "motivasi ialah suatu proses yang tersimpul, salah satu proses yang bertalian dengan a mediating variable. Motivasi ini tak dapat diamati secara langsung, namun tersimpul dari tingkah laku yang tampak. Kita menggunakan konsep motivasi untuk menerangkan tenaga yang mendasari perubahan dalam tingkah laku."

Berdasarkan hasil wawancara dengan Ibu Ruslina Sinaga, guru kelas IV SD Negeri 104196 Hamparan Perak pada tanggal 15 September 2011, mengatakan bahwa banyak sekali permasalahan yang dihadapi guru tersebut dalam melaksanakan pembelajarannya. Salah satunya adalah rendahnya motivasi belajar siswa terhadap mata pelajaran PKn. Hal ini dapat dilihat dari sikap siswa yang tidak tekun dan ulet menghadapi tugas, tidak menunjukkan minat yang tinggi, tidak mandiri, kurang mampu mempertahankan pendapatnya, tidak teguh pendirian, sulit bekerjasama dengan teman, tidak memiliki sikap kesadaran diri sendiri untuk belajar dan kurang memiliki sikap ingin tahu hasil yang diperolehnya.

Menurut siswa kelas IV SD Negeri 104196 Hamparan Perak T.A 2011/2012, mata pelajaran PKn adalah pelajaran yang membosankan karena siswa harus dapat menghapal dan mengingat materi yang disampaikan guru. Rendahnya motivasi siswa tentunya berdampak pada kegiatan belajarnya.

Tujuan utama pendidikan kewarganegaraan adalah menumbuhkan wawasan dan kesadaran bernegara, sikap serta prilaku yang cinta tanah air dan bersendikan kebudayaan bangsa, wawasan nusantara serta ketahanan nasional dalam diri para peserta didik.

Sumarsono (2001:4) menyatakan bahwa dalam Undang-undang Nomor 2 Tahun 1989 tentang Sistem Pendidikan Nasional menjelaskan bahwa "Pendidikan Kewarganegaraan merupakan usaha untuk membekali peserta didik dengan pengetahuan dan kemampuan dasar berkenaan dengan hubungan antara warga negara dan negara serta Pendidikan Pendahuluan Bela Negara (PPBN) agar menjadi warga negara yang dapat diandalkan oleh Bangsa dan Negara Kesatuan Republik Indonesia".

Kurangnya keterampilan guru (memanfaatkan media, memanfaatkan alat dan sumber belajar, melaksanakan metode, model dan teknik mengajar yang beragam), menjadi salah satu penyebab rendahnya motivasi belajar siswa. Dalam praktek mengajar, guru jarang sekali menggunakan metode mengajar yang bervariasi. Metode mengajar yang sering dilaksanakan guru hanya menggunakan metode ceramah dan pemberian latihan-latihan mengerjakan soal sehingga kurang memunculkan motivasi siswa untuk belajar. Selain itu, dalam proses belajar mengajar guru jarang menggunakan media pembelajaran. Padahal penggunaan 
media dapat meningkatkan motivasi siswa untuk belajar karena media merupakan alat yang dapat dibutuhkan guru untuk memudahkan siswa untuk mengembangkan kemampuannya dalam memecahkan masalah.

Penggunaan model pembelajaran mind mapping menyenangkan bagi siswa dan menuntut siswa untuk aktif dalam belajar. Hal ini didukung oleh hasil penelitian Cansera (2011: 70) mengemukakan "motivasi belajar siswa dapat ditingkatkan dengan menggunakan model pembelajaran mind mapping". Hal ini diperoleh dari tingkat keaktifan siswa secara klasikal setelah pelaksanaan siklus II diperoleh sebanyak 40 siswa (77\%) yang mencapai tingkat ketuntasan dengan peningkatan aktivitas belajar pada siklus I yaitu sebesar $(54,75 \%)$.

Model pembelajaran mind mapping merupakan strategi untuk mencatat materi pelajaran dengan menggunakan otak kiri, otak kanan, warna, gambar, serta simbol dalam proses pembuatannya. Mind mapping merupakan cara memetakan pemikiran dalam bentuk gambar yang disusun dalam bentuk radial (memencar).

Olivia (2008: 3) menyatakan "mind mapping merupakan model pembelajaran yang dapat mensinergiskan otak kiri dan otak kanan. Dengan begitu, anak akan "cinta" belajar, dan tidak stres lagi kalau ujian menghadang".

Apakah dengan menggunakan model pembelajaran mind mapping dapat meningkatkan motivasi belajar siswa pada mata pelajaran PKn IV SD Negeri 104196 Hamparan Perak?". Sesuai dengan permasalahan yang telah dikemukakan maka tujuan penelitian ini adalah untuk meningkatkan motivasi belajar PKn siswa pada materi pokok bahasan sistem pemerintahan pusat mengenai tugas dan wewenang lembaga negara. dengan menggunakan model pembelajaran mind mapping di kelas IV SD Negeri 104196 Hamparan Perak.

\section{METODE PENELITIAN}

Penelitian ini adalah Penelitian Tindakan Kelas (PTK) yang dikemukakan oleh Kemmis dan Taggart dalam (Dewi, 2010: 112). Model penelitian ini terdiri dari empat komponen yaitu: 1) perencanaan; 2) tindakan; 3) pengamatan dan 4) refleksi.

Penelitian ini dilakukan pada siswa kelas IV SD Negeri 104196 Hamparan Perak. Penelitian ini berlokasi di desa Tandam Hulu Kecamatan Hamparan Perak Kabupaten Deli Serdang. Subjek dalam penelitian ini adalah siswa kelas IV SD Negeri 104196 Hamparan Perak yang terdiri dari satu kelas berjumlah sebanyak 27 siswa. Objek dalam penelitian ini adalah tindakan sebagai meningkatkan motivasi belajar siswa dalam pelajaran PKn dengan model pembelajaran mind mapping di kelas IV SD Negeri Hamparan Perak.

Motivasi belajar siswa dikelompokkan ke dalam tiga kategori yaitu tinggi, sedang, dan rendah. Aqib (2006: 54) menyusun kriteria tingkat motivasi belajar siswa sebagai berikut: 


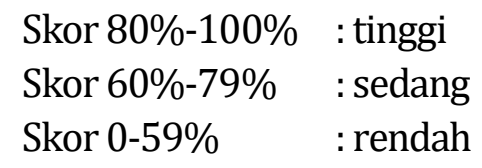

\section{HASIL DAN PEMBAHASAN}

Sebelum siklus I dilaksanakan, dilakukan pengukuran tingkat motivasi siswa dengan melakukan kegiatan pengamatan terhadap perilaku siswa. Pengamatan dilakukan pada saat guru berada di kelas dengan menggunakan alat bantu berupa daftar checklist untuk melihat gejala motivasi belajar siswa pada saat belajar di kelas. Lembar observasi tersebut dikembangkan berdasarkan delapan indikator motivasi yaitu tekun menghadapi tugas, ulet menghadapi kesulitan, menunjukkan minat yang tinggi, mandiri, mudah bosan pada tugas-tugas rutin, dapat mempertahankan pendapatnya, teguh pendirian dan bekerja sama memecahkan masalah. Berdasarkan perilaku yang tampak pada siswa, maka disajikan tingkat pencapaian motivasi belajar siswa pada observasi awal pada tabel 1 berikut,

\section{Siklus I}

1. Perencanaan

Dalam kegiatan perencanaan, dilakukan persiapan seperti penyusunan Rencana Pelaksanaan Pembelajaran (RPP) yang merupakan pedoman dalam melakukan langkah-langkah pembelajaran, membuat alat evaluasi berupa soal, menyiapkan alat dan sumber belajar PKn pada pokok bahasan sistem pemerintahan pusat mengenai tugas dan wewenang lembaga Negara, menyiapkan lembar observasi tingkat motivasi belajar siswa.

2. Pelaksanaan

Pada siklus I dilakukan dua pertemuan. Kegiatan di pertemuan I antara lain mengabsen siswa, memberikan pengarahan tentang model pembelajaran yang akan dilaksanakan, memberikan penjelasan kepada siswa tentang tugas dan wewenang lembaga negara dengan menggunakan model pembelajaran mind mapping. Pertemuan kedua, siswa diberikan pengertian kembali tentang materi pokok sistem pemerintah pusat mengenai tugas dan wewenang lembaga negara dan melanjutkan pembahasan yang belum selesai pada pertemuan I. kegiatan yang dilakukan guru pada pertemuan kedua tidak jauh berbeda dengan pertemuan I. 
Tabel 1. Hasil Observasi Motivasi Belajar Siswa Kondisi Awal

\begin{tabular}{|l|c|c|}
\hline \multicolumn{1}{|c|}{ Hasil } & Capaian & $\mathbf{~ \% ~}$ \\
\hline Tinggi & 0 & 0 \\
\hline Sedang & 14 orang & 52 \\
\hline Rendah & 13 orang & 48 \\
\hline Rata-rata skor & 63 & 50 \\
\hline
\end{tabular}

\section{Observasi}

Pengamatan dilakukan selama kegiatan pembelajaran berlangsung. Mencatat semua hal yang diperlukan dan yang terjadi selama pelaksanaan tindakan berlangsung dengan acuan lembar observasi tingkat motivasi belajar siswa.

4. Refleksi

Setelah pelaksanaan pembelajaran pada siklus I selesai, guru dan peneliti melakukan refleksi. Hal tersebut dilakukan untuk mengidentifikasi kekurangan pada saat pelaksanaan pembelajaran.

a. Keberhasilan, yaitu: tidak ada siswa yang memiliki motivasi belajar rendah, namun motivasi tinggipun tidak ada pula. Jadi keberhasilannya belum maksimal.

b. Hambatan yang dihadapi, yaitu: siswa belum terbiasa dengan pembelajaran mind mapping, siswa belum terlalu mengenal peneliti sehingga siswa masih takut dan malu, siswa masih mengalami kesulitan dalam memahami materi pokok sistem pemerintahan pusat mengenai tugas dan wewenang lembaga negara dengan model pembelajaran mind mapping.

c. Rencana perbaikan pada siklus II, yaitu: memberi penjelasan kembali tentang pembelajaran mind mapping, memberikan tindakan-tindakan yang dapat meningkatkan motivasi belajar siswa, seperti memberikan pujian atau hadiah agar termotivasi dalam belajar.

\section{Siklus II}

1. Perencanaan

Kegiatan perencanaan pada siklus II, disusun berdasarkan hasil refleksi siklus I, dengan memperhatikan hal-hal sebagai berikut: kembali memberi penjelasan tentang model pembelajaran mind mapping, memberikan motivasi kepada siswa dengan penguatan berupa pemberian pujian dan hadiah kecil, mengajak siswa untuk berani mengungkapkan pendapatnya.

2. Pelaksanaan

Peneliti menerapkan skenario pelaksanaan tindakan sesuai dengan skenario pembelajaran yang disusun dalam rencana pembelajaran. Peneliti membimbing siswa untuk lebih kreatif dalam membuat mind mapping. Memberi 
motivasi kepada siswa dengan memberikan penguatan. Peneliti bersama siswa menyimpulkan pembelajaran.

\section{Observasi}

Pengamatan dilakukan oleh peneliti dan guru untuk mengetahui tingkat motivasi belajar siswa. Observasi dilakukan pada saat proses pembelajaran.

4. Refleksi

Berdasarkan hasil yang diperoleh melalui pembelajaran siklus II dapat dikatakan motivasi belajar siswa tergolong tinggi. Hal ini dikarenakan peneliti sudah melaksanakan tindakan-tindakan yang direncanakan pada siklus II. Siswa sudah tidak ribut lagi di dalam kelas saat pembelajaran berlangsung, siswa sudah lebih memperhatikan guru ketika menjelaskan di depan kelas, siswa berani mengeluarkan pendapat dan bertanya serta siswa juga sudah membuat mind mapping sendiri. Siswa pada siklus II ini telah terbiasa dengan model pembelajaran mind mapping, mereka lebih cepat memahami dan termotivasi pada saat pembelajaran PKn. Oleh karena itu, penelitian tindakan kelas berakhir pada siklus II.

Peningkatan motivasi belajar siswa dimulai kondisi awal hingga siklus II, hasilnya disajikan dalam suatu diagram. Adapun diagram yang dimaksud adalah gambar 1.

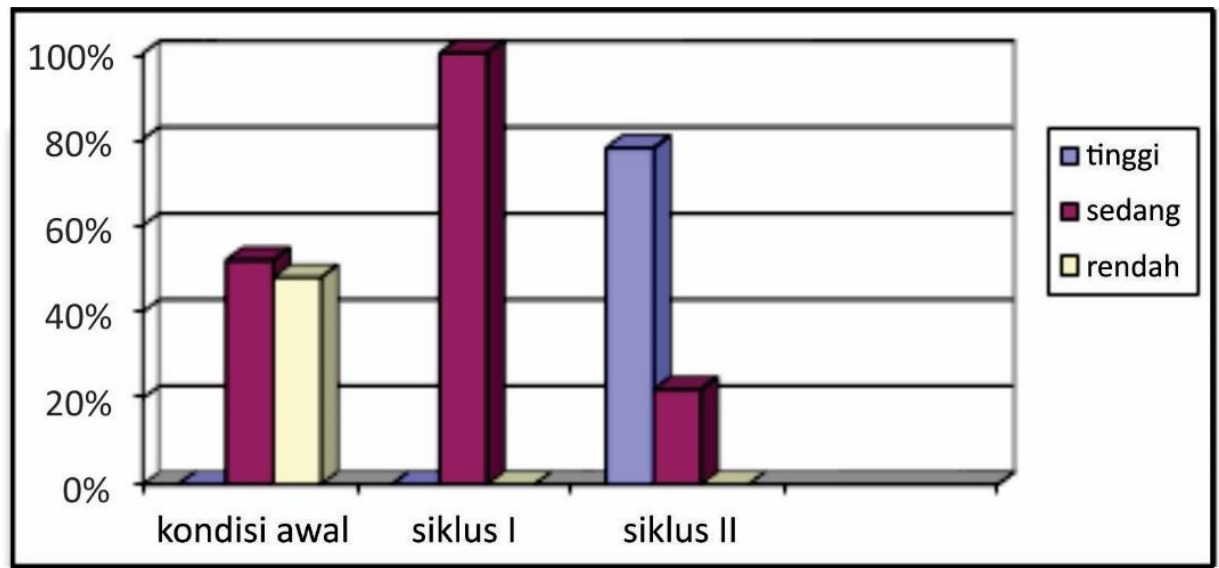

\section{Gambar 1: Persentase Skor Motivasi pada Kondisi Awal Hingga Siklus II}

Berdasarkan gambar 1, dideskripsikan bahwa pada kondisi awal sebelum diterapkan model pembelajaran mind mapping masih sangat rendah dengan skor rata-rata yang diperoleh yaitu 63, persentase skor keseluruhan 50\%, artinya motivasi belajar rendah. Di mana dari jumlah keseluruhan siswa hanya 14 orang (52\%) memiliki motivasi belajar sedang dan motivasi belajar rendah sebanyak 13 orang (48\%). Selanjutnya diberi tindakan pada siklus I yaitu dengan menggunakan model pembelajaran mind mapping. Hasilnya tidak terdapat siswa yang motivasi 
belajarnya tergolong rendah, 27 orang (100\%) tergolong sedang, dan tidak ada siswa yang motivasi belajarnya tinggi dengan rata-rata skor 85, persentase skor keseluruhan 67\%. Hal ini menunjukkan bahwa motivasi belajar siswa pada bidang studi PKn pada materi pokok sistem pemerintahan pusat kelas IV SD Negeri 104196 Hamparan Perak tahun ajaran 2011/2012 tergolong sedang.

Selanjutnya, pada siklus ke II tindakan digunakan dengan model pembelajaran mind mapping rata-rata siswa mencapai skor rata-rata 106, persentase skor keseluruhan siswa 84\%, artinya seluruh siswa memiliki motivasi belajar tinggi. Dimana terdapat 21 (78\%) orang siswa yang memiliki motivasi tinggi, $6(22 \%)$ orang siswa yang memiliki motivasi sedang dan tidak ada siswa yang memiliki motivasi tergolong rendah.

Penggunaan model pembelajaran mind mapping pada pelajaran PKn materi pokok sistem pemerintahan pusat mengenai tugas dan wewenang lembaga negara membuat siswa menjadi lebih aktif, lebih semangat dan lebih termotivasi belajar PKn. Berdasarkan hal tersebut dapat dikatakan bahwa dengan menggunakan model pembelajaran mind mapping pada pelajaran PKn materi pokok pemerintahan pusat mengenai tugas dan wewenang lembaga negara dapat meningkatkan motivasi belajar siswa di kelas IV SD Negeri 104196 Hamparan Perak Tahun Ajaran 2011/2012.

\section{SIMPULAN}

Motivasi belajar siswa mengalami peningkatan setelah diberikan perlakuan dengan menggunakan model pembelajaran mind mapping. Siswa yang motivasi tergolong rendah 13 siswa (48\%) pada kondisi awal menurun menjadi tidak ada siswa yang tergolong rendah tingkat motivasi belajarnya pada siklus I dan II. Siswa yang motivasinya tergolong sedang 14 orang (52\%) pada kondisi awal menjadi meningkat 27 orang (100\%) pada siklus I dan pada siklus II ada 6 orang (22\%) siswa yang tingkat motivasinya sedang. Motivasi belajar siswa yang tergolong tinggi tidak ada pada kondisi awal dan siklus I, pada siklus II motivasi belajar siswa yang tergolong tinggi 21 orang (78\%). 
REKOGNISI Vol.1 No.1 Desember 2016: 92-100

\section{DAFTAR PUSTAKA}

Buzan, T. 2005. Buku Pintar Mind Map. Jakarta: Gramedia Pustaka Utama.

.2008. Buku Pintar Mind Map untuk Anak. Jakarta : Gramedia Pustaka Utama.

Cansera, U. 2011. Meningkatkan Motivasi Belajar Siswa Pada Pelajaran Matematika dengan Menggunakan Model Mind Mapping di Kelas V SD Negeri 108075 Deli Tua Tahun Ajaran 2010/2011. Skripsi. Medan: Universitas Negeri Medan.

Dewi, 2010. Profesionalisasi Guru Melalui Penelitian Tindakan Kelas. Medan: Unimed.

Hamalik, O. 2008. Kurikulum dan Pembelajaran. Jakarta: Bumi Aksara.

Olivia, F. 2009. Gembira Belajar dengan Mind Mapping. Jakarta: Gramedia.

Sardiman. 2009. Interaksi dan Motivasi Belajar Mengajar. Jakarta: Raja Grafindo Persada.

Soemanto, W. 2006. Psikologi Pendidikan. Jakarta: Rineka Cipta. 